\title{
THE 'IRRATIONAL' FEMALE WAS INVENTED BY THE PATRIARCHAL SOCIETY
}

\author{
by Sara Hartman*
}

\section{Introduction}

The main research problem that will be addressed is the reasons why a patriarchal system of law developed. This will be addressed by looking at the shifts in natural law, the rise of positivism and modernity and thus a restricted jurisprudence all of which contributed to a male dominated system to the exclusion of females.

The following assumptions can be presumed from this research problem. Firstly, the shifts in natural law with the rise of modernity and restricted jurisprudence and the development of the positive law have favoured the development of a patriarchal system. These changes can be seen as factors which facilitated the development of a patriarchal system. For example, from the importance of the community to a shift to the individual, a shift from a prescribed duty to that of unrestricted freedom; a shift from divine law to the laws made by man and; a shift of morality to survival of the fittest (where women were deemed as the weaker sex) et cetera. These shifts coupled with the development of positive law and the rise in restricted jurisprudence have led to a male dominated society in which the 'irrational' female's only place is in the home.

Secondly, it can be assumed that the law and those it governs may be better off if the law was not an ingrained, prescribed patriarchal system of rules and commands but rather an all-encompassing system which makes provision for every social being through a general jurisprudence. This essay will thus suggest and explore how this patriarchal society and the law is challenged through the rise of feminism, general jurisprudence, legal pluralism and even uBuntu.

Thirdly, it can be assumed that substantive equality would be more beneficial than a formal equality through the incorporation of a 'feminine law' in order to make place for emotions, compassion and the so called 'irrationality' of females.

* Third year LLB student, University of Pretoria. 
Theoretical challenges to this patriarchal legal system will be looked at in order to achieve substantive equality over formal equality. In order to make this analysis, one must take into account the intersectionality of individuals through a general jurisprudence, over a restricted jurisprudence. This is necessary in order to achieve transformation from a legal system that supposedly protects everyone but favours only that of the rich, white male. In a South African context, the Constitution becomes an important tool in order to achieve substantive equality. As it is both a monument and a memorial which protects the rights of all citizens, irrespective of class, gender, sex et cetera, the Constitution caters for every citizen's intersectionality, thus making it necessary for substantive equality.

\section{Shifts in natural law that contributed to the development of the patriarchal system}

By looking at these shifts the origin of patriarchy will be traced within these theories. It will show how these shifts favoured the development of patriarchy throughout history and how it led to a modern patriarchal society today in response to the first assumption.

Natural law can be traced as far back as $442 B C$ when Sophocles staged a play showing the trial of Antigone. ${ }^{1}$ Here Sophocles demonstrates that man could not override the unchanging laws of the gods. He believed in a higher law, not created by legislatures made of men, which could therefore not be overridden by the positive law of the state. Instead, a higher duty is established according to relationships between man and the gods and between human beings themselves (the community or cosmos is more important than the individual.) Here the female Antigone stands before the King and challenges him. She does not fear man because the gods and their law are on her side. ${ }^{2}$

The next shift was that of the Sophists ${ }^{3}$ where the authority of the gods lost its force. Man was now seen as the measure of all things and thus the free and self-serving individual took centre focus. According to Callicles natural law consists of the strong man who should live to his utmost power and give way to his natural desires. This view lacked morality and natural law became a disregard for any rules with only the powerful individual allowed to be in charge. The beginnings of a patriarchal system have started to develop in the law (not necessarily in history; even at this point in time women were still subordinate to

1 W Le Roux 'Natural law theories' in C Roederer \& D Moellendorff (eds) Jurisprudence (2004) 6.

2 Le Roux (n 1 above) 27.

3 Le Roux (n 1 above) 30 \& 31. 
men, but in the law where the natural desires of men become more prevalent and are now protected and justified by that law.)

If we look at the next shift, Plato ${ }^{4}$ rejects the written laws of the state and the individualistic, radical law that Callicles suggests. Aristotle ${ }^{5}$ believed that a judge's task is to find a just solution which was to be found in relationships of nature; not merely to apply laws. This propensity to revert back to nature instead of merely applying laws can be contrasted to positivism. Already here, it can be seen that the law should not be applied blindly but rather a just solution (in other words a substantive equality) should be sought in order to serve the community justly rather than the individual. Even though women were confined to the home, there was more of an overall benefit to the community in terms of the law.

A new understanding of natural law came from the Stoics ${ }^{6}$ who moved natural law from the external to the internal where the inner state of mind must be in harmony with a universal reason. All individuals became equal before the law and their rights were determined by a universal law that was applicable everywhere and at all times. This approach would have been more beneficial for women because the law would have provided some protection but it did not last as it was a temporary period in legal history which was replaced by the next shift.

Augustine ${ }^{7}$ claimed that justice could only be obtained through the presence of God. The will of God now replaced the will of man. Obedience to God was now the only moral imperative to the exclusion of morals in every other aspect of life. Aquinas ${ }^{8}$ then tried to reconcile God with reason. He identifies two types of law within natural law; divine law and positive law (which recognises private property and individual ownership.) This rise in subjective rights shifted the focus once again from the community to the individual. This shift to the individual, particularly the dominant male, could have further developed the patriarchal society as wealthy men were the only ones who could acquire such rights. As men were the paterfamilias, women and children were subjugated to men's control under those households, similarly to that of females on the homestead in an African context.

The next shift came about with William Ockham ${ }^{9}$ who defended the nominalist view as well as voluntarism. He re-asserts the primacy of God's will as prime, free and absolute. According to this view there

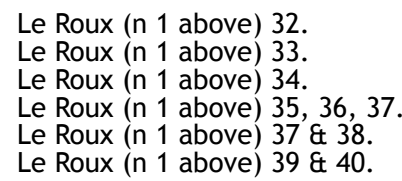


are only words to describe nature. This disenchanted view of nature was one from which no meaning or guidance could be derived. Thus modern law developed as a coordinated system of subjective rights. From this thinking came Hugo Grotius ${ }^{10}$ who claimed that ownership (a subjective right) is wilful, not naturally given, by agreement or contract. Thus ownership as a share in the common world turned into an unlimited, subjective power of the individual. This way of thinking once again favours the wealthy male, who can afford to acquire ownership rights, which places power and control in their hands.

The next shift can be characterised by Thomas Hobbes, ${ }^{11}$ who believed in an unlimited sovereign power where every person confers all their power and strength onto the state in terms of a social contract. This is undesirable because the state could be corrupt or based on unequal, unjust principles which would be implemented without question as the state has full power. The state would not be held accountable as it has the power to define what a right is and what it deems just. Citizens would then have to abide by it in terms of the social contract, thus creating a platform in which patriarchy can flourish. John Locke $^{12}$ found this problematic. He rather combined natural law with subjective rights developed by Grotius to provide an objective moral limit to the power of the state and its positive laws. This, however, does not stop those laws from being rooted with patriarchy.

This 'denunciation of women in the early doctrinal and constitutional writings of common law was the repression of a figure of femininity. "13 Thus we have a 'classic, liberal (male) vision of social life as the exercise of subjective rights' where these subjective rights belong to 'individuals [primarily men] wielding absolute power within legally circumscribed' positive laws. ${ }^{14}$

Lastly, in a South African context, the struggle lawyers ${ }^{15}$ appealed to a higher duty that all lawyers have to respect the natural law which demands respect for basic human rights. They rejected the positive laws of the state because it did not meet the standards of the natural law. Nelson Mandela believed that every African has a 'conflict between his conscience ... and the law.' A conflict between the morality of people and the legality of laws of the state (just because something is law does not mean it is fair). A duty arises to oppose these positivist laws when they disregard the morals and wellbeing of the society they govern. This view by Mandela can not only be applied to an opposition of apartheid for black African people but can also be

10 Le Roux (n 1 above) 40.

11 Le Roux (n 1 above) 41 \& 42.

12 Le Roux (n 1 above) 43, 44, 45.

13 P Goodrich Oedipus lex: Psychoanalysis, history, law (1995) 12.

14 Le Roux (n 1 above) 44.

15 Le Roux (n 1 above) 25 \& 26. 
utilised for women of all races who are oppressed by these positivist laws. For example white women in South Africa were enfranchised only on 19 May $1930 .{ }^{16}$ Considering how long women were excluded from the right to vote before this date, 1930 was just the other day in the broader timeline of history. The point, is that immoral laws excluding women were enforced blindly by lawyers and the state without consideration of the rights of women in terms of equality. Women of all races were subject to this male dominant law, some more so than others but not because of their gender but based on skin colour. Mandela urges against this blind following and urges for a law that encompasses the rights and morals of all citizens not only to combat racism but to combat a patriarchal society as well. Meaningful transformation in the law is what Mandela pleads for: Law that reflects the conscience of the social identity ${ }^{17}$ of a new South Africa and not one that is contra bonos mores; law that takes into account the intersectionality ${ }^{18}$ of the people which it governs, factors such as race, gender, class, etcetera that make a person who they are. People consist of multiple facets and in order to achieve substantive equality, these factors must be taken into account.

\section{Positivism, modernity and the rise of restricted jurisprudence}

In relation to what Mandela says above, John Dugard ${ }^{19}$ also criticises positivism. Positivism, according to John Austin and Jeremy Bentham ${ }^{20}$ in nineteenth-century England, was based on the command theory which states that the law is a set of commands connected to a punishment where the state's power is unlimited as it is the creator of law. According to this view there is a strict separation between law and morality. This positivism was adopted in South Africa because of the decrease of natural law and the increasing influence of English law. ${ }^{21}$ This can be seen with the purely mechanical function of judges who merely find the intention of the legislature and apply it, with no creative power. Thus was in order to keep in line with the separation of powers principle. ${ }^{22}$ This positivism is what has laid the foundation for a patriarchal system of law. The

16 South African History Online 'The women's suffrage movement' http:// www.sahistory.org.za/archive/womens-suffrage-movement (accessed 18 May 2015).

17 C Douzinas \& A Gearey Critical jurisprudence: The political philosophy of justice (2005) 1.

18 D Bell 'Who's afraid of critical race theory' (1995) University of Illinois Law Review 893-910.

19 J Dugard 'The judicial process, positivism and civil liberty' (1971) 88 South African Law Journal 181.

20 Dugard (n 19 above) 184 \& 185.

21 Dugard (n 19 above) 184.

22 Dugard (n 19 above) 186 
status of women dates back to Plato and Aristotle who tried to find the role of women in society. ${ }^{23}$ They came to the conclusion that women should be confined to the private sphere as they were thought of as irrational and incapable of handling life in the public sphere particularly in politics. Thus the law was created by a sovereign made up of men who did not consider the equality of women. Legal systems thus reflect the characteristics of their largely male architects who are legislatures and judges. ${ }^{24}$

Dugard suggests that the judiciary should not play a merely mechanical role but that they should be guided by accepted legal values. ${ }^{25} \mathrm{He}$ further suggests that a positivist approach when interpreting statutes is a pretence that hides 'inarticulate premises, 26 within these statutes. The worth of the individual is important and constitutional values (particularly that of the South African Constitution which is based upon equality, freedom and human dignity) should be taken into account during the judicial process. This is particularly important for women as this will give them the necessary power from the law that is needed for transformation from a patriarchal system to a system that empowers every individual.

With the rise of modernity came a rise of restricted jurisprudence. According to Douzinas the evolution of jurisprudence started in a premodern time where natural law theories were prevalent leading to a general jurisprudence. ${ }^{27}$ They argue that as modernity rose and the positivist theories became more prevalent a rise of restricted jurisprudence or impoverished law occurred. ${ }^{28}$

Restricted jurisprudence is said to be a set of strict rules and outcomes that produce a set of desired results $^{29}$ similarly to positivism theory. Lawyers and judges are forced to abide by these rules rather than relying on any personal opinions or experiences that they might have in other disciplines. ${ }^{30}$ The law must contain legality and not personal, political or moral values. ${ }^{31}$ The law can be shortened, memorized and regurgitated because it lacks influence from other disciplines leading to an impoverishment in the law. ${ }^{32}$ This impoverished law would favour the development and implementation of a patriarchal system because such laws would be applied and enforced regardless of their fairness even if they are immoral. Even if

23 H Barnett Introduction to feminist jurisprudence (1998) 3.

Barnett (n 23 above) 26.

Dugard (n 19 above) 187 \& 195.

Dugard (n 19 above) 187.

Douzinas \& Geary (n 17 above) 1 \& 2.

Douzinas \& Geary (n 17 above) 4 \& 6.

9 J Boyd White 'Justice in tension: an expression of law and the legal mind' (2012) 9 No Foundations 4, 10 \& 14; Douzinas \& Geary (n 17 above) 4.

30 K Klare 'Legal culture and transformative constitutionalism' (1998) 14 South African Journal on Human Rights 146 \& 149.

31 Klare (n 30 above) 158.

32 Douzinas \& Geary (n 17 above) 4. 
they are blatantly discriminatory to women they will be learnt, taught and enforced as a set of strict rules with no deviation in order to achieve a desired result. Modernity, along with the rise of restricted jurisprudence is said to negate legal pluralism because a restricted jurisprudence favours a single unified system of law based on patriarchy which excludes all other pluralities including the law from a female voice. This further reasserts a patriarchal system of law.

Therefore, the shifts in natural law combined with the development of the positive law (and its acceptance in South Africa) together with a rise of modernity and restricted jurisprudence, have favoured the implementation of a patriarchal society and system of law which responds to the first assumption.

\section{An all-encompassing system of law is needed for transformation}

The law and those it governs (especially females) may be better off if society was not an ingrained, prescribed patriarchal system but rather an all-encompassing system that makes provision for every social identity. So the question is whether a general jurisprudence is the answer to this second assumption?

General jurisprudence is an expansion of the law through different influences, sources and disciplines. The law should be an open system of interpretation, creativity and language. ${ }^{33}$ Boyd White argues that we are 'free to use every resource at our disposal' such as religion, public opinion and social theories in order to interpret the $\mathrm{law}^{34}$ in order to find a just outcome rather than one already prescribed by positive law. Democratic values, such as human dignity, freedom and equality, should be taken into account in order for the law to provide justice especially for fundamental human rights. ${ }^{35}$

Thus a system of general jurisprudence would be a better approach to follow as it makes room for the intersectionality of individuals and allows the law to become an all-encompassing law where the conscience of a nation ${ }^{36}$ is taken into account rather than blindly following a set of strict rules bringing it in line with constitutional values. Douzinas argues that the law is starting to return to a more general jurisprudence as awareness of the need for justice and human rights becomes widespread and a new hermeneutical jurisprudence arises. ${ }^{37}$ This rise in a general

33 Boyd White (n 29 above) 16.

34 Boyd White (n 29 above) 17.

35 Klare (n 30 above) 149

36 Le Roux (n 1 above) 25

37 Douzinas \& Geary (n 17 above) 1 \& 7. 
jurisprudence is challenging patriarchal law favoured by a restricted jurisprudence thus providing an answer to the second assumption.

\section{Theoretical machinery that has challenged patriarchal ideals to achieve general jurisprudence.}

Firstly, the importance of memory must be looked at. Klare argues that in order for 'transformative constitutionalism' to occur, constitutional enactment and interpretation must not be done in isolation but taking into account the historical context of the law. ${ }^{38}$ The past is an important tool for transformation as it enables us to reflect on prior mistakes, to learn from them and not to repeat those atrocities again.

Feminism thus sought to challenge patriarchal structures by opposing the roles in which men had placed them. Females began to demand equality ${ }^{39}$ and aimed to break down this socially constructed ${ }^{40}$ male society. Substantive equality over formal equality can be used to challenge this patriarchal society as it would take into account things such as the 'irrationality' of females, emotions, class and other social factors (in other words the intersectionality of individuals) which the positive law attempted to keep out. Liberal feminism may be too close to a restricted jurisprudence and a formal equality. However, it contains some merit; formal equality is still needed in the law as it allows for the right to vote, right to education and so on but it needs to go beyond this which is why substantive equality is needed. Cultural and relational feminism would provide the necessary challenge to patriarchy and provide for substantive equality. Cultural and relational feminism ${ }^{41}$ is based on an essentialist view that embraces the differences between men and women. These differences that women have should be celebrated ${ }^{42}$ and embraced in the law rather than shut out. This makes room for a general jurisprudence and more than one system of law in terms of legal pluralism. ${ }^{43}$ Peter Goodrich advocates for a minor jurisprudence, more specifically a feminine jurisprudence, which he believes is a 'challenge to the science of law and a threat to its monopoly of legal

38 Klare (n 30 above) 150.

39 Barnett (n 23 above) 4. Feminism began to reflect the demands of women, irrespective of their race, age or class as they wanted to be recognised as equal parties to the social contract.

40 Barnett (n 23 above) 4.

41 This can be seen as part of 2 nd and 3rd wave feminism.

42 Anonymous Feminist Theory 'Examining Branches of Feminism' http://www. sascwr.org/files/www/resources_pdfs/feminism/

Definitions_of_Branches_of_Feminisn.pdf (accessed 30 May 2015).

$43 \mathrm{~S}$ Veitch et al Jurisprudence: Themes and concepts (2007) 248. 
knowledge-44 - in essence, a threat to patriarchy. Minor jurisprudence is neither merely poetic nor aesthetic but a threat to the history of the practices to which they were tied ${ }^{45}$ (a history saturated with patriarchy) which is why minor jurisprudences have been denied.

Another challenge to patriarchy (not only to be used for indigenous (aw) is the principle of $u B u n t u^{46}$ together with cultural feminism. uBuntu contains aspects that can be embraced in the struggle against patriarchy. For example, uBuntu in its most fundamental meaning describes humaneness and morality. It promotes group solidarity and unity. This is important for the survival of the group and an individual's well-being is relative to that of the group. Thus by excluding females, it violates the morality and humaneness of uBuntu. It is detrimental to the group because half of that group is oppressed. uBuntu is a 'humanistic orientation towards fellow beings ${ }^{4} 7$ thus irrelevant of gender. Therefore, feminism can use these values from uBuntu in order to challenge patriarchy to achieve meaningful transformation.

Lastly, in terms of a South African context, the Constitution is both memorial and monument. ${ }^{48}$ The memorial aspect is used to remember the past. It reminds us of a time of inequality, not only in terms of apartheid and race but also in terms of where women were treated as inferior to men. This is important as it acts as a constant reminder that the past must never be repeated; it was a gross violation of human rights. But the Constitution also serves as a monument. It serves to remind us of the victories that have been won, of how far we have come and how far we still have to go. It acts as a safeguard that protects the equality, human dignity and freedom of all those who fall under its protection. The Constitution is the supreme law of the Republic but it is not an 'all-encompassing, super law.' The principle of subsidiarity ${ }^{49}$ means that other legislation, statutes, cases etcetera should be used first before relying on the Constitution in order to solve legal problems. To respond to the third assumption; meaningful transformation and substantive equality, will only be possible if legislation is free from patriarchy and embraces a general jurisprudence.

44 P Goodrich Law in the courts of love: Literature and other minor jurisprudences (1996) 1.

45 Goodrich (note 44 above) 2, 3.

46 Y Mokgoro 'uBuntu and the law in South Africa' in D Cornell \& N Mavangua (eds) uBuntu and the law: African ideals and post-apartheid jurisprudence (2012) 317.

47 Mokgoro (n 50 above) 318.

48 L Du Plessis 'The South African constitution as monument and memorial, and the commemoration of the dead' in R Christensen \& P Bobo (eds) Rechtstheorie in rechtspraktischer Absicht (2008) 189.

49 Du Plessis (n 48 above) 194. 
The law, like history, mourns as it recognises the past which will make a 'deeper impression on the soul and be retained in the memory more than all the memorials that have been rehearsed. ${ }^{50}$ Peter Goodrich emphasises the importance of history that enables us to mourn for the past and its atrocities. Mourning and emotions are feminine traits, which he states are important as mourning creates a long lasting impression on the soul that allows us to accept and move forward towards transformation.

\section{Conclusion}

The main problem of patriarchy in the law has been discussed by looking at the shifts in natural law, the development of positivism and the rise of modernity with a restricted jurisprudence. This problem was responded to and has shown how the 'irrational' woman was created through the process. It can be seen that patriarchy through time has been consistent and there hasn't been any significant challenges to it yet because patriarchy is still evident within the public sphere throughout the world. Theoretical suggestions were made that can be used to challenge this patriarchal law such as feminism combined with uBuntu in order to achieve a general jurisprudence that incorporates the intersectionality of individuals and legal pluralism so that transformation can be realised. Transformation according to Nelson Mandela is important because 'deny[ing] people their human rights is to challenge their very humanity.' 